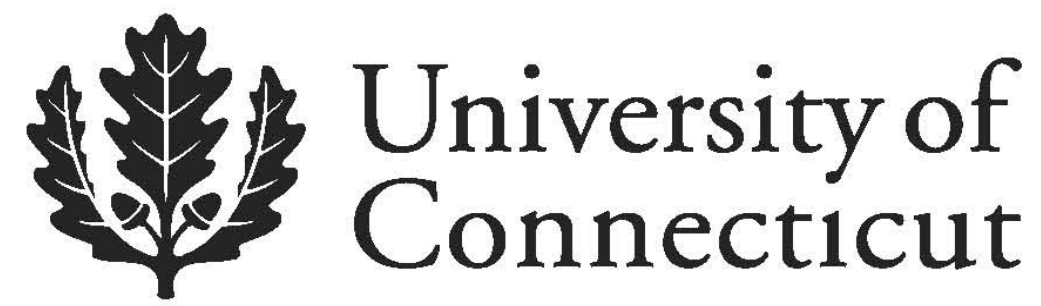

Department of Economics Working Paper Series

\title{
The Effect of Growth Volatility on Income Inequality
}

Ho-Chuan Huang

Tamkang University

WenShwo Fang

Feng Chia University

Stephen M. Miller

University of Nevada, Las Vegas

University of Connecticut

Working Paper 2012-09

June 2012

341 Mansfield Road, Unit 1063

Storrs, CT 06269-1063

Phone: (860) 486-3022

Fax: (860) 486-4463

http://www.econ.uconn.edu/

This working paper is indexed on RePEc, http://repec.org/ 


\title{
The Effect of Growth Volatility on Income Inequality
}

\author{
Ho-Chuan (River) Huang \\ Department of Banking and Finance \\ Tamkang University \\ WenShwo Fang \\ Department of Economics \\ Feng Chia University \\ Stephen M. Miller * \\ Department of Economics \\ University of Nevada, Las Vegas
}

June 5, 2012

\begin{abstract}
This paper assesses the long-run effect of growth volatility on income inequality using a comprehensive panel of annual U.S. state-level data during the 1945 to 2004 period. Using the pooled mean group (PMG) estimator, we find overwhelming evidence supporting the hypothesis that larger growth volatility positively and significantly associates with higher income inequality. In addition, our key finding is robust to alternative lag structures, conditioning variables, inequality measures, volatility indicators, and time periods.
\end{abstract}

Keywords: Income Inequality, Growth Volatility, Mean Group Estimator, Pooled Mean Group Estimator

JEL Classification: C23, D31, O40

\footnotetext{
* Corresponding author: Stephen M. Miller, Department of Economics, University of Nevada, Las Vegas, Las Vegas, NV, 89154-6005, USA; e-mail: stephen.miller@unlv.edu. The authors are grateful to Jonathan Temple for constructive suggestions, and M. Hashem Pesaran and Mark W. Frank for sharing the GAUSS code and data, respectively, used in this paper. Any remaining errors are our own responsibility.
} 


\section{Introduction}

The interrelationships amongst the economic (income) growth, growth volatility, and income distribution (inequality) have generated separate strands in the existing growth literature. One broad strand assesses the effect of growth volatility on growth. While conventional wisdom suggests a standard dichotomy in that business cycle volatility and growth are unrelated (Lucas, 1987), other theoretical models predict that growth volatility negatively affects growth (Bernanke, 1983; Pindyck, 1991; Aizenman and Marion, 1993) or positively affects it (Mirman, 1971; Black, 1987). In an influential empirical paper, Ramey and Ramey (1995) use two panels of countries and conclude that economies with higher volatility experience lower growth. Hnatkovska and Loayza (2005) confirm that volatility negatively affects growth and that the negative link largely depends on the country's structural characteristics. Kose, Prasad, and Terrones (2006) find that the negative relationship between volatility and growth becomes weaker in the 1990s because of trade and financial integration. Imbs (2007), however, shows that, while volatility negatively affects growth across countries, it positively affects growth across sectors.

Another broad strand of research explores the effect of income inequality on growth. Galor and Zeira (1993), Alesina and Rodrik (1994), and Persson and Tabellini (1994) argue theoretically that income inequality harms growth through fiscal redistribution and distortion, sociopolitical instability, or imperfect financial markets mechanisms; while Kaldor (1957), Saint-Paul and Verdier (1993) and Galor and Tsiddon (1997a, 1997b) assert that income inequality exerts a positive effect on growth through incentive, saving rate, or investment indivisibility channels. A similar divide exists at the empirical level. While Alesina and Rodrik (1994), Persson and Tabellini (1994), Wan, Lu, and Chen (2006), and Sukiassyan (2007) provide strong evidence that 
income inequality negatively influences growth, Partridge (1997, 2005), Li and Zou (1998), Forbes (2000), and Lundberg and Squire (2003) show that income inequality positively affects growth. Barro (2000) uncovers a nonlinear inequality-growth nexus, with inequality encouraging growth in rich economies but slowing it in poor countries. Similarly, Lin, Huang, Kim, and Yeh (2009) determine that an increase in inequality accelerates growth in high-income countries but hinders growth in low-income ones.

Rather than examining the volatility-growth or the inequality-growth linkages, a recent strand of literature considers a third possible connection between the level of growth volatility and the extent of income inequality. Current theories reveal at least three channels that can explain how growth volatility affects the distribution of income. First, Caroli and García-Peñalosa (2002) consider an economy where random shocks affect output. Therefore, the labors' marginal products and their wages fluctuate over time. As such, risk-averse labors willingly accept a decrease in their average earnings in exchange for a constant wage, offered by risk-neutral entrepreneurs. Thus, the more volatile the output, the greater the risk premium that labor willingly foregoes, and the larger the share of income seized by the entrepreneurs. As a result, more volatile economies probably associate with worsened income distribution. This is called the wage setting mechanism.

Second, Checchi and García-Peñalosa (2004) extend the seminal work of Galor and Zeira (1993) by considering the influence of risk on the accumulation of human capital. Assuming decreasing absolute risk aversion, they show that non-labor (inherited) wealth performs as an insurance mechanism, and only individuals with sufficiently high inheritance (non-labor wealth) will pursue risky human capital investment. Thus, riskier economies (i.e., larger output volatility) require higher non-labor wealth to accumulate human capital. Consequently, a more volatile economy will exhibit fewer average years 
of education and a greater degree of educational inequality and, hence, a higher level of income inequality. This is called the human capital investment mechanism.

Third, García-Peñalosa and Turnovsky (2005) propose a stochastic endogenous growth model to explore the relationship between the volatility of growth and the distribution of factor income. In particular, the employment level is endogenously determined and the production structure allows for non-constant labor shares. Under realistic values of the degree of risk aversion, greater output uncertainty increases saving and promotes growth, thereby raising (future) wages and the supply of labor. As a result, the return to capital rises and that to labor falls. Since capital endowments exhibit more unequal distribution than labor time, the change in relative factor prices will raise income inequality. This is called the labor supply decision mechanism.

Hausmann and Gavin (1996) verify empirically that compared with industrial countries (and East-Asian tigers), Latin American economies experience much more unequal income distributions and much more volatile economic growth rates. Laursen and Mahajan (2004) find that output volatility negatively influences equality (the income share of the bottom quintile). Using data on a cross-section of developing and developed countries, Breen and García-Peñalosa (2005) find that a more volatile growth rate positively associates with higher degrees of income inequality. More recently, Calderón and Yeyati (2009) show that volatility, especially adverse extreme output drops, exerts negative and persistent effects on equity and poverty. All these empirical findings support the theoretic prediction

This paper empirically re-visits the volatility-inequality nexus and contributes to the literature in the following important respects. First, instead of using cross-country data as in Breen and García-Peñalosa (2005), we rely on a large annual panel data for 48 states in the continental U.S. during the period 1945-2004. The existing literature 
generally accepts the idea that cross-country data, especially income inequality indicators, more likely suffer from the problems of limited observations, measurement errors, and incompatibility. Our use of the within-country (across states) data may mitigate those difficulties because the panel is large (2880 observations); the data are more consistently measured, and, thus, are more homogeneous in nature. ${ }^{1}$ In this respect, our paper complements that of Breen and García-Peñalosa (2005), and provides a more clear-cut conclusion on the relationship between volatility and inequality.

Second, most studies rely on cross-sectional (panel) data on developed and developing countries to explore the effect of growth volatility on income inequality. These cross-country studies face the problems of structural, cultural, and other differences between the panel of countries, developed and developing. For instance, while Ramey and Ramey (1995) establish that a strong and negative association exists between volatility and growth, Kose, Prasad, and Terrones (2006) show that this negative relationship significantly weakens with both trade and financial integration. Iyigun and Owen (2004) demonstrate that whether greater income inequality associates with more or less volatility in consumption growth (real GDP growth) depends on the level of economic development. As such, the volatility-inequality relationship probably responds to the level of economic and financial development, the extent of liberalization, the degree of globalization, and so on. Our use of the within-country, across-state data presumably mitigates, if not immunizes, our analysis from such criticism.

Third, we implement a panel error-correction approach instead of the conventional method of time averaging (using cross-sectional data), following the arguments in Loayza and Ranciére (2006). While averaging obviously loses information, it remains

\footnotetext{
${ }^{1}$ For example, see Section 3 Data Description. When we divide the national panel-data set into sub-samples for the four Census regions - the Midwest, Northeast, South, and West, both the average inequality measures and the volatility measures do not vary much from the national outcomes.
} 
unclear whether averaging over fixed-length intervals effectively eliminates cyclical fluctuations. Moreover, averaging hides the dynamic relationship amongst important variables and eliminates useful information for estimating a more flexible model. The use of the pooled mean-group estimator, introduced by Pesaran, Shin, and Smith (1999), permits not only the control for individual (state-specific) effects that might invalidate the results of cross-sectional analysis, but also the identification of the long-run equilibrium (cointegrating) relationship amongst the variables of interest, whether such variables are stationary or nonstationary.

Our empirical results strongly support a long-run cointegrating relationship between growth volatility and income inequality with a positive and statistically significant effect. As such, our findings confirm the theoretical prediction that larger growth volatility worsens the distribution of income. Moreover, this key finding continues to hold when we use alternative lag orders, different conditioning information sets, alternative inequality indicators, different volatility measures, and different time periods.

The organization of the paper is as follows. Section 2 discusses the empirical model and estimation issues. Section 3 describes the data sources and properties. Section 4 presents our main results as well as a variety of robustness checks. The last section concludes.

\section{Empirical Strategy}

Consider the long-run equilibrium relationship between y and x. In a panel data context, we can specify the model as follows:

$$
y_{i t}=\theta_{0 i}+\theta_{i}^{\prime} x_{i t}+\epsilon_{i t}
$$

where $\mathrm{y}_{\mathrm{it}}$ stands for income inequality, and $\mathrm{x}_{\mathrm{it}}$ equals a $(\mathrm{k} \times 1)$ vector of explanatory 
variables, including a measure of growth volatility in state i at time t, respectively. Our main question focuses on the coefficient of the growth volatility variable. Clearly, a significantly positive (negative) estimate of this coefficient indicates that higher income inequality is associated with larger (lower) growth volatility.

Pesaran, Shin, and Smith (1999), Catão and Solomou (2005), and Catão and Terrones (2005) argue that equation (1) nests itself in an autoregressive distributed lag (ARDL) model such that $y_{i t}$ adjusts to changes in the explanatory variables $x_{i t}$, if any. In particular, the ARDL $(p, q, \cdots q)$ model (i.e., the dependent and independent variables enter the right-hand side with lags of order $\mathrm{p}$ and $\mathrm{q}, \cdots \mathrm{q}$, respectively) is written as follows:

$$
y_{i t}=\sum_{j=1}^{p} \lambda_{i j} y_{i, t-j}+\sum_{j=0}^{q} \delta_{i j}^{\prime} x_{i, t-j}+\mu_{i}+\epsilon_{i t}
$$

where $\mu_{\mathrm{i}}$ denotes the state-specific (fixed) effects. ${ }^{2}$

For convenience, we re-parameterize equation (2) in a panel-data error-correction form follows:

$$
\Delta y_{i t}=\emptyset_{i}\left[y_{i, t-1}-\theta_{i}^{\prime} x_{i t}\right]+\sum_{j=1}^{p-1} \lambda_{i j}^{*} \Delta y_{i, t-j}+\sum_{j=0}^{q-1} \delta_{i j}^{*} \Delta x_{i, t-j}+\mu_{i}+\epsilon_{i t}
$$

where $\emptyset_{\mathrm{i}}=-\left(1-\sum_{\mathrm{j}=1}^{\mathrm{p}} \lambda_{\mathrm{ij}}\right), \theta_{\mathrm{i}}=-\beta_{\mathrm{i}} / \emptyset_{\mathrm{i}}, \beta_{\mathrm{i}}=\sum_{\mathrm{j}=0}^{\mathrm{q}} \delta_{\mathrm{ij}}$,

$$
\lambda_{\mathrm{ij}}^{*}=-\sum_{\mathrm{m}=\mathrm{j}+1}^{\mathrm{p}} \lambda_{\mathrm{im}}, \mathrm{j}=1,2, \cdots, \mathrm{p}-1,
$$

and

\footnotetext{
${ }^{2}$ Working with the ARDL model, as argued in Catão and Solomou (2005) and Catão and Terrones (2005), mitigates the contemporaneous feedback and reverse causality running from income inequality $\left(y_{i t}\right)$ to growth volatility $\left(x_{i t}\right)$, since all right-hand side variables enter the regression lagged by at least one period. The ARDL model also dispense with (panel) unit-root pretesting of the variables, since the model permits both stationary and nonstationary variables in the estimation.
} 


$$
\delta_{i j}^{*}=-\sum_{m=j+1}^{q} \delta_{i m}, j=1,2, \cdots, q-1 .
$$

Note that the parameter $\emptyset_{\mathrm{i}}$ measures the error-correcting speed of adjustment. If income inequality and growth volatility as well as the other conditioning variables are cointegrated, we expect a significantly negative $\emptyset_{\mathrm{i}}$ such that the variables converge to long-run equilibrium. As a result, finding a significantly negative $\emptyset_{\mathrm{i}}$ constitutes evidence of a long-run cointegrated (equilibrium) relationship. Moreover, the parameter of main interest is $\theta_{\mathrm{i}}$, which measures the long-run effects of growth volatility (along with other explanatory variables) on income inequality. The parameter $\delta_{\mathrm{ij}}^{*}$ captures the short-run relationships.

We can estimate equation (3) using the mean group (MG) estimator (Pesaran and Smith, 1995) and the pooled mean-group (PMG) estimator (Pesaran, Shin, and Smith, 1999). Both approaches allow the intercepts, short-run coefficients, and error variances to differ across states. The PMG approach imposes homogeneous restriction on the long-run parameters while the MG method allows long-run coefficients to differ for each individual state. If the long-run homogeneous restrictions hold, then the PMG technique produces consistent and efficient estimators. We can test the validity of a long-run homogeneity restriction and, hence, the suitability of the PMG estimator, using a standard Hausman-type statistic. For more detailed discussion, interested readers should consult Pesaran, Shin, and Smith (1999).

\section{Data Description}

The data set consists of a large panel of annual data for the 48 states of the continental U.S. from 1945 to 2004, which forms a balanced panel data set with $\mathrm{N}=48$ and $\mathrm{T}=60$, 
a total of 2,880 observations. ${ }^{3}$ Frank (2009) constructs and uses this data set to examine the effect of income inequality on economic growth. In particular, the comprehensive data set includes relevant annual measures on income distribution. As in Frank (2009), we prefer to measure income inequality with the share of income held by the top 10 percent of the population (top10), constructed from the IRS tax return data. Feenberg and Poterba (2000) note that IRS data proves most reliable for producing income shares at the top end of the distribution, but proves less reliable at the lower end due to low-income households not filing tax returns. Further, we decompose the share of income held by the top 10 percent of the population and consider the income share of the top 1 percent (top1) and the income share of the top 90 to 99 percent (top9099) of the population, respectively. Additionally, we also consider the Gini coefficient (gini), the Atkinson index with inequality aversion parameter of 0.5 (atkin05), and the Theil entropy index (theil), as additional measures of income inequality. We multiply all inequality variables by 100 from the original data, which Frank (2009) kindly provided.

We cannot observe our major independent variable, growth volatility. We must derive an operational measure of volatility to consider the effect of volatility on inequality. To this end, we utilize several popular nonparametric and parametric approaches in the existing literature to construct alternative proxies for growth volatility.

We adopt three nonparametric measures of growth volatility. We first calculate the growth rate of output by the first differences of the logarithm of real state income per capita multiplied by 100. Following Pritchett (2000), we measure growth volatility as the five-year moving average of the absolute value of the change in the rate of growth

\footnotetext{
3 The construction of growth and volatility variables, however, reduces the number of usable observations.
} 
$\left(\operatorname{adg}_{i t}\right)$, which serves as our primary volatility indicator. For robustness check, our second measure follows Arize, Osang, and Slottje (2000) and proxies the growth volatility by the five-year moving sample standard deviation of the growth rate $\left(\mathrm{mg}_{\mathrm{it}}\right)$. Our third nonparametric volatility index, following Breen and García-Peñalosa (2005), calculates the five-year moving standard deviation of the absolute value of the change in the rate of growth $\left(\mathrm{mdg}_{\mathrm{it}}\right)$.

We also adopt three parametric measures of growth volatility. Following Byrne and Davis (2005a, 2005b), we estimate GARCH-type models and collect the (square root of) fitted conditional variances as parametric proxies of growth volatility. In particular, we consider three popular alternatives, a GARCH (generalized autoregressive conditional heteroscedasticity) model, an EGARCH (exponential GARCH) model, and a CGARCH (component GARCH) model. Basically, a standard GARCH model consists of mean and variance equations. For each state i, we fit an $\operatorname{ARMA}(p, q)$ (autoregressive moving average) model for the mean equation of the growth rate, ${ }^{4}$

$$
g_{t}=a_{0}+\sum_{j=1}^{p} a_{j} g_{t-1 j}+\sum_{j^{\prime}=1}^{q} b_{j^{\prime}} \epsilon_{t-j^{\prime}}
$$

where $\epsilon_{\mathrm{t}}$ is a white noise. We choose a simple model for $\mathrm{p}$ and $\mathrm{q}$ using the Akaike Information criterion (AIC) or the Schwarz Bayesian criterion (SBC) which selects fewer lags. To allow for conditional heteroskedasticity, we assume that

$$
\epsilon_{\mathrm{t}} \mid \Omega_{\mathrm{t}-1}=\mathrm{h}_{\mathrm{t}}^{\frac{1}{2}} \eta_{\mathrm{t}}
$$

where $\Omega_{t-1}$ denotes information set up to time $t-1, h_{t}$ represents the conditional variance at time t, and $\eta_{t} \sim N I D(0,1)$.

\footnotetext{
${ }^{4}$ For notational simplicity, we omit the subscript i for the state.
} 
As mentioned, we estimate three alternative GARCH models to obtain the conditional heteroskedasticity $h_{t}$. First, we use the GARCH $(1,1)$ specification proposed by Bollerslev (1986) as follows: ${ }^{5}$

$$
\mathrm{h}_{\mathrm{t}}=\alpha_{0}+\alpha_{1} \epsilon_{\mathrm{t}-1}^{2}+\beta \mathrm{h}_{\mathrm{t}-1} \text {. }
$$

Second, we adopt the exponential GARCH model introduced by Nelson (1991). The EGARCH model permits asymmetric responses to positive and negative shocks. The EGARCH(1,1) specification for the conditional variance function is written as follows:

$$
\operatorname{In}\left(\mathrm{h}_{\mathrm{t}}\right)=\alpha_{0}+\alpha_{1}\left|\frac{\epsilon_{\mathrm{t}-1}}{\sqrt{\mathrm{h}_{\mathrm{t}-1}}}\right|+\alpha_{1}^{\prime} \frac{\epsilon_{\mathrm{t}-1}}{\sqrt{\mathrm{h}_{\mathrm{t}-1}}}+\beta \operatorname{In}\left(\mathrm{h}_{\mathrm{t}-1}\right) .
$$

Third, we use an extension of the basic GARCH model by Engle and Lee (1999), who specify modified GARCH(1,1) model as follows:

$$
\mathrm{h}_{\mathrm{t}}=\bar{\mu}+\alpha_{1}\left(\epsilon_{\mathrm{t}-1}^{2}-\bar{\mu}\right)+\beta\left(\mathrm{h}_{\mathrm{t}-1}-\bar{\mu}\right) .
$$

This specification imposes mean reversion to $\bar{\mu}$, which is a constant for all time. They further modify this model into a CGARCH model which permits mean reversion to a varying level $\mu_{\mathrm{t}}$ as follows:

$$
\begin{gathered}
\mathrm{h}_{\mathrm{t}}=\mu_{\mathrm{t}}+\alpha_{1}\left(\epsilon_{\mathrm{t}-1}^{2}-\mu_{\mathrm{t}-1}\right)+\beta\left(\mathrm{h}_{\mathrm{t}-1}-\mu_{\mathrm{t}-1}\right) \text { and } \\
\mu_{\mathrm{t}}=\omega+\rho\left(\mu_{\mathrm{t}-1}-\omega\right)+\mathrm{Q}\left(\epsilon_{\mathrm{t}-1}^{2}-\mathrm{h}_{\mathrm{t}-1}\right) .
\end{gathered}
$$

After fitting equation (4) along with equation (5), (6), and (8) for each state and period, and taking square root of the fitted conditional variances, we can obtain three parametric measures of growth volatility hg, heg, and hcg, respectively.

In addition to our main explanatory variable (i.e., growth volatility), we follow the current literature by including the level of economic development to control for the well-known Kuznets effects (i.e., the income distribution first worsens and then improves with economic development, Kuznets, 1955). Specifically, we include the

\footnotetext{
${ }^{5}$ We can easily extend the equation to a more general GARCH(p, q) specification.
} 
logarithm of the state-level real per capita income (a proxy for the level of economic development) and its squared term in the regression. In addition, we include two measures of human capital attainment - high school and college - in logarithmic form, as additional controlling variables in later analysis. ${ }^{6}$ For a more detailed description and definition of the variables, see Frank (2009).

Table 1 provides summary statistics on the main variables. The correlations between any pair of inequality indicators are positive, large, and significant at the 1-percent level. The correlations between any pair of volatility measures, while smaller, are also significantly positive at the 1-percent level. The simple correlation coefficients between any income inequality indicator and growth volatility measure are all significantly negative at the 1-percent level.

We also subdivide the panel-data set into sub-samples for the four Census regions - the Midwest, Northeast, South, and West. $^{7}$ The average inequality measures across regions do not vary much from the national outcomes. For example, the average share of income earned by the top 10-percent of the population equals 33.6 percent for the nation as a whole, while it equals 32.7, 34.0, 34.2, and 33.4 percent for the Midwest, Northeast, South, and West, respectively. A similar pattern generally emerges for the other inequality measures.

For the volatility measures, we find that the full sample exhibits the lowest

\footnotetext{
${ }^{6}$ Frank (2009) constructs high school and college as the fraction of the state population with a high-school or college degree.

${ }^{7}$ The states included in each region are as follows: Midwest (Illinois, Indiana, Iowa, Kansas, Michigan, Minnesota, Missouri, Nebraska, North Dakota, Ohio, South Dakota, and Wisconsin); Northeast (Connecticut, Maine, Massachusetts, New Hampshire, New Jersey, New York, Pennsylvania, Rhode Island, and Vermont); South (Alabama, Arkansas, Delaware, Florida, Georgia, Kentucky, Louisiana, Maryland, Mississippi, North Carolina, Oklahoma, South Carolina, Tennessee, Texas, Virginia, and West Virginia); and West (Arizona, California, Colorado, Idaho, Montana, New Mexico, Nevada, Oregon, Utah, Washington, and Wyoming). The summary statistics for the four Census regions are available from the authors.
} 
variability of the five samples, whereas the Midwest exhibits more variability than the other three Census regions. ${ }^{8}$ For example, the volatility from the $\operatorname{GARCH}(1,1)$ specification (i.e., hg) yields measures of 2.19 for the full sample and 4.23, 2.62, 3.03, and 2.76 for the Midwest, Northeast, South, and West, respectively. Note that the Midwest posts the least inequality amongst the four Census regions and at the same time posts the highest volatility. This crude finding as well as the negative correlation for the nation suggests that a negative relationship may exist between income inequality and output growth volatility (i.e., unconditional). Our empirical analysis finds the opposite outcome (i.e., conditional), however.

We also consider the average level and growth rate of real per capita income, leading to the following observations. Connecticut sees the highest average real per capita income (i.e., \$27,650) and also experiences the highest standard deviation and range, which runs from the lowest to highest real per capita income. At the other end of the distribution, Mississippi experiences the lowest average real per capita income (i.e., \$14,118). Montana, however, experiences the lowest standard deviation and range for real per capita income. Mississippi exhibits the highest growth rate (i.e., 2.24 percent) of real per capita income, while Nevada exhibits the lowest growth rate (i.e., 1.18 percent). In addition, North Dakota sees the highest standard deviation and range for real per capita income growth. Finally, New Jersey experiences the lowest standard deviation and Oregon experiences the lowest range for real per capita income growth.

\section{Empirical Results}

\subsection{Main Findings}

This section presents our main empirical results using the top 10-percent share of

\footnotetext{
${ }^{8}$ Complete data for this and the next paragraph are available from the authors.
} 
income (i.e., top $10_{\mathrm{it}}$, for each state $\mathrm{i}$ and period $\mathrm{t}$ as the dependent variable), which is our preferred measure of income inequality across states and over time. We use growth volatility, which we calculate by the five-year moving mean of the absolute values of the changes in the growth rates (i.e., $\operatorname{adg}_{\text {it }}$ ), as our key independent variable. As a starting point, we consider a baseline $\operatorname{ARDL}(1, \cdots, 1)$ model, where both the dependent and independent variables enter the regression with only one lag. Table 2 reports the primary estimates of the long-run effect of growth volatility on income inequality for the 48 state panel over the 1945 to 2004 period. ${ }^{9}$ Regression (1) contains the growth volatility variable, while regression (2) includes two additional determinants of income inequality, the level of economic development (measured by the logarithm of real state income per capita) and its squared term, to control for the Kuznets effect.

We estimate equation (2) using the PMG and MG techniques, which permits non-stationary series. As discussed above, the MG estimator imposes no restrictions on the long-run coefficients. In contrast, the PMG approach imposes common long-run effects (i.e., the long-run parameters of all the explanatory variables are the same across states). If we cannot reject these restrictions, both the PMG and MG estimators produce consistent estimates, but the PMG estimator is more efficient. To determine the more appropriate estimator, we rely on the joint Hausman-type test, based on the comparison between the PMG and MG estimates. Under the null hypothesis of homogeneous long-run parameters, the Hausman test statistics equal 2.4559 and 3.9554 with p-values of 0.1171 and 0.2663 , respectively, when we do and do not control for the Kuznets effect. Obviously, we cannot reject the slope homogeneity restriction at conventional significance levels, suggesting identical long-run parameters across states. Accordingly,

\footnotetext{
${ }^{9}$ For brevity, we omit all the short-run estimation results. These results are available on request.
} 
we conclude that the PMG method produces not only consistent, but also efficient, estimates, which we prefer. ${ }^{10}$ Thus, our analysis will focus on the estimates obtained with the favorable PMG outcomes. ${ }^{11}$

Before discussing our primary findings, we examine whether a long-run relationship (dynamic stability) exists amongst inequality, volatility, and other covariates. As Loayza and Ranciére (2006, p. 1059) point, it requires that a negative coefficient on the error-correction term (i.e., $\lambda_{\mathrm{i}}=-\left(1-\phi_{\mathrm{i}}\right)$ ) between 0 and -2 (i.e., $\lambda_{\mathrm{i}}$ lies within the unit circle). We strongly support this condition, as the (average) error-correction coefficients $\emptyset_{\mathrm{i}}$ are both negative and significant at the 1-percent level, with or without the economic development variables. Therefore, a long-run equilibrium (cointegrated) relationship exists, implying meaningful long-run estimates. Specifically, the estimated long-run effect of growth volatility (adg) on income inequality (top10) equals 0.1659 and 0.1450 in regressions (1) and (2), respectively. Both estimates are positive and statistically significant at the 1-percent level, indicating that larger growth volatility affects the distribution of income in an adverse way and produces higher income inequality, as predicted by many theories. Note that a long-run, positive relationship between inequality and volatility sharply contrasts with the simple negative correlations reported in Table 1. Other things equal, a two-standard deviation increase in the top decile share of income (approximately 9.2604 percent) associates with an increase in the long-run growth rate of real per capita state income of 2.4059 percent, a quite large magnitude.

\footnotetext{
10 As argued in Loayza and Ranciére (2006), a key requirement to ensure the consistency of the PMG estimates is the independence of the regression residuals across states. In reality, non-zero error covariances likely arise from omitted common factors that influence the states' ARDL processes. Therefore, we follow Loayza and Ranciére (2006) and Frank (2009) to difference the variables from their cross-section means in an attempt to eliminate these common factors.

11 The MG estimate displays a negative long-run effect of growth volatility on income inequality sometimes in Tables 2, 3, 4, 5, and 8, but never significantly.
} 
In addition, the coefficient estimate of the (log of) real state income per capita and its squared term equal -49.5418 and 2.5180 , respectively. Both estimates are statistically significant at the 1-percent level. These results suggest that a U-shaped association exists between inequality and development, and, in particular, the distribution of income first improves and then worsens as the economy advances. ${ }^{12}$ Most importantly, after controlling for the possible Kuznets effect, growth volatility continues to exert a positive and significant effect on income inequality.

While our main interest concerns the effect of growth volatility on income inequality, the existence of a long-run cointegrating relationship between inequality and volatility suggests that the causation can run both ways. For instance, suppose that the wealthy concentrate in one sector, say financial services. Shocks to the financial services sector then primarily affect the wealthy, which disproportionately affects aggregate volatility. Catão and Solomou (2005, p. 1268) and Catão and Terrones (2005, p. 535) argue that using the ARDL specification in equation (2), where all explanatory variables enter the regression lagged by at least one period, can alleviate any contemporary causality running from income inequality to growth volatility (along with other variables). We, thus, estimate the model by using the lagged values of growth volatility as well as other explanatory variables to mitigate potential endogeneity (reverse causality) issues. Table 3 reports PMG and MG estimates. The results qualitatively match those summarized in Table 2 when we measure the growth volatility variables as the current rather than lagged values. Again, the Hausman test statistics do not reject the joint homogeneity of all long-run parameters at conventional levels of

\footnotetext{
12 Although the evidence contradicts the inverted-U prediction of Kuznets (1955), several authors document similar and quite standard findings of the U-shaped pattern by using the U.S. state-level data (Ram 1991, Partridge, Rickman, and Levernier 1996, and Piketty and Saez 2003, 2006). Finally, the minimum point on the $U$ lies within the relevant range of real state income per capita.
} 
statistical significance. The PMG estimates prove more efficient than their MG counterparts. The coefficients of growth volatility remain positive and statistically significant at the 5-percent or better level. Consistent with the findings of Table 2, the results support the view that growth volatility significantly and positively drives income inequality.

\subsection{Robustness Checks}

This section performs a battery of experiments to see if our key finding that higher growth volatility associates with larger income inequality remains robust to (1) the different lag orders of the ARDL models, (2) additional explanatory variables, (3) alternative income inequality indicators, (4) other growth volatility measures, and (5) different time periods. Tables 4 to 8 summarize, respectively, the corresponding estimation results along with specification tests. Taken as a whole, we find that the Hausman tests cannot reject the slope homogeneity restrictions for the explanatory variables in all cases, suggesting that we should emphasize the results obtained using the PMG estimator. Furthermore, all error-correction estimates are negative and statistically significant at the 1-percent level, and fall within the dynamically stable range, indicating that there exists a long-run cointegrating relationship between income inequality and growth volatility (along with other variables).

First, we consider the optimal order of lags selected by the AIC, the SBC, and the HQ (Hannan and Quinn) (all up to 3 lags) for each state, respectively. Table 4 summarizes the empirical outcomes. Across all specifications, the PMG estimates of growth volatility are positive and statistically significant at the 1-percent level, lending additional support to our earlier finding that growth volatility positively links to income inequality. Our primary finding remains robust to changes in the lag structure of the 
main variables.

Second, we add (individually or jointly) two human capital attainment variables to assess whether the long-run coefficients of growth volatility on income inequality depends on the inclusion of extra education variables. Table 5 presents the results. In every case, the coefficient on the growth volatility variable is always significantly positive at the 1-percent level, irrespective of the conditioning variables. Consequently, our main result that more unstable growth rate relates to more unequal income distribution continues to hold. The inequality-development link is again characterized by a U-shaped profile. Two education variables exert a significant inequality-reducing effect when they enter the regression in a separate way. When entered jointly, however, only the effect the proportion of the population with at least a college degree remains significantly negative, although only at the 10-percent level.

Third, we explore whether the key result continues to hold by using several distinct inequality measures. Table 6 displays the results from using the PMG estimator and five different measures of income inequality (separately) as the dependent variable but keeping adg as the key growth volatility variable. The alternative income inequality indicators include the income share of the top 1-percent (top1) population, the income share of the top 90-99-percent (top9099) of the population, the Gini coefficient (gini), the Atkinson index with inequality aversion parameter of 0.5 (atkin05), and the Theil entropy index (theil). Across all measures of income inequality, growth volatility remains a significant explanatory variable of alternative income inequality measures. All long-run coefficients on growth volatility are positive and statistically significant at the 5-percent level or better. Thus, larger growth volatility associates with higher income inequality.

Fourth, we consider alternative volatility measures. Table 7 presents the results 
from using six different indicators of volatility, but returns to the preferred inequality measure (top10) as the dependent variable. Specifically, we consider the five-year moving-sample standard deviations of the growth rates (mg), the five-year moving standard deviation of the absolute values of the changes in the rate of growth (mdg), the square root of fitted conditional variances from a GARCH model (hg), from an exponential GARCH model (heg), from a component GARCH model (hcg), and the 5-year moving average of the absolute values of the changes in the unemployment rate $\left(\operatorname{adg}_{\mathrm{it}}^{\mathrm{ur}}\right){ }^{13}$ respectively. Except for mdg (at the 10-percent level) and adg $\mathrm{ur}_{\mathrm{it}}^{\mathrm{ur}}$ (at the 5-percent level), all PMG estimates on alternative growth volatility indicators are positive and statistically significant at the 1-percent level. The systematic findings confirm that macroeconomic instability negatively affects the distribution of income, regardless of the measures of growth volatility.

Finally, the IRS tax data used by Frank (2009) to construct income inequality measures probably creates systematic measurement error, especially before the expansion of the earned income tax credit in 1986/1987. While the earlier IRS income data censored individuals below a threshold level of income, the 1986/1987 expansion makes it more likely that almost everyone including the poor files tax returns. Obviously, its consequence not only affects, say, the Gini coefficient, but also affects the top-decile measures of inequality such as top10 and/or top1. As one solution we re-estimate the specification with data from 1987 to 2004. Table 8 reports the results with this alternative time period. We continue to find that growth volatility exerts a positive and statistically significant influence on income inequality, suggesting that the positive inequality-volatility association probably does not reflect the problem of data

\footnotetext{
${ }^{13}$ We thank Jonathan Temple for this suggestion.
} 
quality.

\section{Conclusion}

This paper complements existing cross-country studies by utilizing a comprehensive panel of state-level inequality data for 48 states in U.S. over the postwar (1945-2004) period and by implementing the pooled mean-group estimator to assess the long-run effects of growth volatility on income inequality. The high-quality data set uses more comparable information (especially for measures of income inequality) than cross-country counterparts. Moreover, the econometric technique employed can estimate long-run effects, and, at the same time, permits both $\mathrm{I}(0)$ and $\mathrm{I}(1)$ variables. Accordingly, we obtain a more definite answer on the precise relationship between income inequality and growth volatility.

The Hausman-type test suggests that the long-run parameters on growth volatility are identical across states and the significantly negative error-correction coefficients support a long-run, cointegrating relationship between inequality and volatility. The inequality-volatility linkage is always positive and statistically significant. Thus, the central finding suggests that larger growth volatility strongly associates with higher income inequality. Our results not only confirm the empirical conclusions, such as Breen and García-Peñalosa (2005) who use cross-country data, but also provide evidence consistent with the theoretical conjectures of Caroli and García-Peñalosa (2002), Checchi and García-Peñalosa (2004), and García-Peñalosa and Turnovsky (2005). Moreover, the sensitivity checks indicate that our findings remain relevant to alternative lag orders, conditioning variables, inequality measures, volatility indicators, and time periods. 


\section{References}

Aizenman, J., and Marion, N., 1993. Policy Uncertainty, Persistence and Growth. Review of International Economics 1, 145-163.

Alesina, A., and Rodrik, D., 1994. Distributive Politics and Economic Growth. Quarterly Journal of Economics 99, 465-490.

Arize, A. C., Osang, T., and Slottje, D. J., 2000. Exchange Rate Volatility and Foreign Trade: Evidence from Thirteen LDCs. Journal of Business \& Economic Statistics $18,10-17$.

Barro, R. J., 2000. Inequality and Growth in a Panel of Countries. Journal of Economic Growth 5, 5-32.

Bernanke, B. S., 1983. Irreversibility, Uncertainty, and Cyclical Investment. Quarterly Journal of Economics 98, 85-106.

Black, F., 1987. Business Cycles and Equilibrium. Cambridge, MA: Blackwell.

Bollerslev, T., 1986. Generalized Autoregressive Conditional Heteroskedasticity. Journal of Econometrics 31, 307-327.

Breen, R., and García-Peñalosa, C., 2005. Income Inequality and Macroeconomic Volatility: An Empirical Investigation. Review of Development Economics 9, 380-398.

Byrne, J. P., and Davis, E. P., 2005a. Investment and Uncertainty in the G7. Review of World Economics 141, 1-32.

Byrne, J. P., and Davis, E. P., 2005b. The Impact of Short- and Long-Run Exchange Rate Uncertainty on Investment: A Panel Study of Industrial Countries. Oxford Bulletin of Economics and Statistics 67, 307-329.

Calderón, C., and Yeyati, E. L., 2009. Zooming In: From Aggregate Volatility to Income Distribution. Policy Research Working Paper, World Bank.

Caroli, E., and García-Peñalosa, C., 2002. Risk Aversion and Rising Wage Inequality. Economics Letters 77, 21-26.

Catão, L. A. V., and Solomou, S. N., 2005. Effective Exchange Rates and the Classical Gold Standard Adjustment. American Economic Review 95, 1259-1275.

Catão, L. A. V., and Terrones, M. E., 2005. Fiscal Deficits and Inflation. Journal of Monetary Economics 52, 529-554.

Checchi, D., and García-Peñalosa, C., 2004. Risk and the Distribution of Human Capital. Economics Letters 82, 53-61.

Engle, R. F., and Lee, G. J., 1999. A Long Run and Short Run Component Model of Stock Return Volatility. In Engle, R. F., and White, H., (eds), Cointegration, Causality and Forecasting: A Festschrift in Honour of Clive W. J. Granger, Oxford University Press, Oxford, 475-497.

Feenberg, D. R., and Poterba, J. M., 2000. The Income and Tax Share of Very High-Income Households, 1960-1995. American Economic Review 90, 264-270. 
Forbes, K. J., 2000. A Reassessment of the Relationship between Inequality and Growth. American Economic Review 90, 869-887.

Frank, M. W., 2009. Inequality and Growth in the United States: Evidence from a New State-Level Panel of Income Inequality Measures. Economic Inquiry 47, 55-68.

Galor, O., and Tsiddon, D., 1997a. Technological Progress, Mobility, and Economic Growth. American Economic Review 87, 363-382.

Galor, O., and Tsiddon, D., 1997b. The Distribution of Human Capital and Economic Growth. Journal of Economic Growth 2, 93-124.

Galor, O., and Zeira, J., 1993. Income Distribution and Macroeconomics. Review of Economic Studies 60, 35-52

García-Peñalosa, C., and Turnovsky, S. J., 2005. Production Risk and the Functional Distribution of Income in a Developing Economy: Tradeoffs and Policy Responses. Journal of Development Economics 76, 175-208.

Hausmann, R., and Gavin, M., 1996. Securing Stability and Growth in a Shock Prone Region: The Policy Challenges for Latin America. In: Hausmann, R., and Reisen, H., (eds), Securing Stability and Growth in Latin America. OECD, Paris.

Hnatkovska, V., and Loayza, N., 2005. Volatility and Growth. In: Aizenman, J., and Pinto, B., (eds), Managing Economic Volatility and Crises: A Practitioner's Guide. Cambridge University Press. .

Imbs, J., 2007. Growth and Volatility. Journal of Monetary Economics 54, 1848-1862.

Iyigun, M. F., and Owen, A. L., 2004. Income Inequality, Financial Development, and Macroeconomic Fluctuations. Economic Journal 114, 352-376.

Kaldor, N., 1957. A Model of Economic Growth. Economic Journal 67, 591-624.

Kose, M. A., Prasad, E. S., and Terrones, M. E., 2006. How Do Trade and Financial Integration Affect the Relationship Between Growth and Volatility? Journal of International Economics 69, 176-202.

Kuznets, S., 1955. Economic Growth and Income Inequality. American Economic Review 45, $1-28$.

Laursen, T., and Mahajan, S., 2004. Volatility, Income Distribution, and Poverty. In: Aizenman, J., and Pinto, B., (eds), Managing Volatility and Crisis: A Practitioner's Guide. Washington, DC: The World Bank, 101-136.

Li, H., and H. Zou (1998), Income Inequality Is Not Harmful for Growth: Theory and Evidence. Review of Development Economics, 2, 318-334.

Lin, S. C., Huang, River H. C., Kim, D. H., and Yeh, C. C., 2009. Nonlinearity between Inequality and Growth. Studies in Nonlinear Dynamics and Econometrics 13(2), Article 3.

Loayza, N., and Ranciére, R., 2006. Financial Development, Financial Fragility, and Growth. Journal of Money, Credit and Banking 38, 1051-1076.

Lucas, R., 1987. Models of Business Cycles. Oxford: Blackwell.

Lundberg, M., and Squire, L., 2003. The Simultaneous Evolution of Growth and Inequality. Economic Journal 113, 326-344. 
Mirman, L., 1971. Uncertainty and Optimal Consumption Decisions. Econometrica 39, 179-185.

Nelson, D. B., 1991. Conditional Heteroskedasticity in Asset Returns: A New Approach. Econometrica 59, 347-370.

Partridge, M. D., 2005. Does Income Distribution Affect U.S. State Economic Growth. Journal of Regional Science 45, 363-394.

Partridge, M. D., 1997. Is Inequality Harmful for Growth? Comment. American Economic Review 87, 1019-1032.

Partridge, M. D., Rickman, D. S., and Levernier, W., 1996. Trends in U.S. Income Inequality: Evidence from a Panel of States. Quarterly Review of Economics and Finance 36, 17-37.

Persson, T., and Tabellini, G., 1994. Is Inequality Harmful for Growth? American Economic Review 84, 600-621.

Pesaran, M. H., Shin, Y., and Smith, R. P., 1999. Pooled Mean Group Estimation of Dynamic Heterogeneous Panels. Journal of the American Statistical Association 94, 621-634.

Pesaran, M. H., and Smith, R. P., 1995. Estimating Long-Run Relationships from Dynamic Heterogeneous Panels. Journal of Econometrics 68, 79-113.

Piketty, T., and Saez, E., 2003. Income Inequality in the United States, 1913-1998. Quarterly Journal of Economics 118, 1-39.

Piketty, T., and Saez, E., 2006. The Evolution of Top Incomes: A Historical and International Perspective. American Economic Review Papers and Proceedings 96, 200-205.

Pindyck, R. S., 1991. Irreversibility, Uncertainty, and Investment. Journal of Economic Literature 29, 1110-1048.

Pritchett, L., 2000. Patterns of Economic Growth: Hills, Plateaus, Mountains, and Plains. World Bank Economic Review 14, 367-391.

Ram, R., 1991. Kuznets's Inverted-U Hypothesis: Evidence from a Highly Developed Country. Southern Economic Journal 57, 1112-1123.

Ramey, G., and Ramey, V. A., 1995. Cross-Country Evidence on the Link Between Volatility and Growth. American Economic Review 85, 1138-1151.

Saint-Paul, G., and Verdier, T., 1993. Education, Democracy, and Growth. Journal of Development Economics 42, 399-407.

Sukiassyan, G., 2007. Inequality and Growth: What Does the Transition Economy Data Say? Journal of Comparative Economics 35, 35-56.

Wan, G., Lu, M., and Chen, Z., 2006. The Inequality-Growth Nexus in the Short and Long Run: Empirical Evidence from China. Journal of Comparative Economics 34, 654-667. 
Table 1: Summary Statistics of Main Variables

\begin{tabular}{|c|c|c|c|c|c|c|c|c|c|c|c|c|}
\hline \multicolumn{13}{|c|}{ basic statistics } \\
\hline & top10 & top1 & top9099 & gini & atkin05 & theil & adg & $\mathrm{mg}$ & mdg & hg & heg & hcg \\
\hline mean & 33.5938 & 9.9065 & 23.6873 & 49.2559 & 19.6895 & 46.1807 & 3.0768 & 2.8538 & 4.1385 & 3.1923 & 3.3325 & 3.2058 \\
\hline std. dev. & 4.6302 & 3.2697 & 2.5410 & 6.1534 & 3.8839 & 13.7211 & 1.6215 & 2.1791 & 3.5494 & 1.7792 & 1.7009 & 1.7168 \\
\hline $\min$ & 24.5610 & 5.9378 & 17.2124 & 35.4757 & 12.3881 & 26.5774 & 0.2916 & 0.1333 & 0.2716 & 0.0773 & 0.5311 & 0.0179 \\
\hline $\max$ & 52.6957 & 27.5244 & 37.6985 & 69.1699 & 37.4397 & 115.9014 & 14.9434 & 19.4922 & 35.4568 & 24.6651 & 27.2642 & 18.6142 \\
\hline observations & 2880 & 2880 & 2880 & 2880 & 2880 & 2880 & 2640 & 2640 & 2592 & 2814 & 2814 & 2814 \\
\hline & \multicolumn{12}{|c|}{ correlation matrix } \\
\hline top10 & 1.0000 & & & & & & & & & & & \\
\hline top1 & 0.8479 & 1.0000 & & & & & & & & & & \\
\hline top9099 & 0.7311 & 0.2582 & 1.0000 & & & & & & & & & \\
\hline gini & 0.8829 & 0.6193 & 0.8118 & 1.0000 & & & & & & & & \\
\hline atkin05 & 0.9588 & 0.7978 & 0.7205 & 0.8799 & 1.0000 & & & & & & & \\
\hline theil & 0.9556 & 0.8597 & 0.6351 & 0.8145 & 0.9618 & 1.0000 & & & & & & \\
\hline adg & -0.3560 & -0.2687 & -0.3124 & -0.4222 & -0.3738 & -0.3252 & 1.0000 & & & & & \\
\hline $\mathrm{mg}$ & -0.3101 & -0.2089 & -0.3055 & -0.3374 & -0.3678 & -0.3176 & 0.8232 & 1.0000 & & & & \\
\hline mdg & -0.3023 & -0.2198 & -0.2797 & -0.3022 & -0.3504 & -0.3150 & 0.7599 & 0.9365 & 1.0000 & & & \\
\hline hg & -0.3288 & -0.2178 & -0.3215 & -0.3856 & -0.3872 & -0.3460 & 0.7035 & 0.7094 & 0.7069 & 1.0000 & & \\
\hline heg & -0.1990 & -0.1393 & -0.1848 & -0.2243 & -0.2497 & -0.2237 & 0.5653 & 0.6072 & 0.6074 & 0.7479 & 1.0000 & \\
\hline hcg & -0.3305 & -0.2049 & -0.3414 & -0.4091 & -0.3945 & -0.3490 & 0.6902 & 0.6790 & 0.6812 & 0.9104 & 0.7498 & 1.0000 \\
\hline
\end{tabular}

a. The income inequality indicator is measured by (1) the share of income held by the top 10 percent (top10) of the population, (2) the income share of the top 1 percent (top1) of population, (3) the income share of the top 90-99 percent (top9099) of the population, (4) the Gini coefficient (gini), (5) the Atkinson index with inequality aversion parameter of 0.5 (atkin05), and (6) the Theil entropy index (theil), respectively.

b. The growth volatility is constructed by (1) the five-year moving mean of the absolute values of the changes in the rate of growth (adg), (2) the five-year moving standard deviation of the growth rate (mg), (3) the five-year moving standard deviation of the absolute values of the changes in the rate of growth (mdg), (4) the square root of the fitted conditional variances from the GARCH model (hg), (5) the square root of the fitted conditional variances from the exponential GARCH model (heg), and (6) the square root of the fitted conditional variances from the component GARCH model (hcg), respectively.

c. All correlation coefficients are significant at 1-percent level. 
Table 2: Effects of Growth Volatility on Income Inequality

\begin{tabular}{|c|c|c|c|c|}
\hline & \multicolumn{2}{|c|}{ (1) } & \multicolumn{2}{|c|}{$(2)$} \\
\hline & PMG & MG & PMG & MG \\
\hline \multicolumn{5}{|l|}{ Error Correction Coefficient } \\
\hline$\varphi$ & $\begin{array}{c}-0.3605^{* * *} \\
(0.0311)\end{array}$ & $\begin{array}{c}-0.3844 * * * \\
(0.0325)\end{array}$ & $\begin{array}{c}-0.3775^{* * *} \\
(0.0307)\end{array}$ & $\begin{array}{c}-0.5671^{* * *} \\
(0.0259)\end{array}$ \\
\hline \multicolumn{5}{|l|}{ Long-Run Coefficients } \\
\hline Growth Volatility (adg ${ }_{i t}$ ) & $\begin{array}{c}0.1659 * * * \\
(0.0362)\end{array}$ & $\begin{array}{c}0.2754 * * * \\
(0.0787)\end{array}$ & $\begin{array}{c}0.1450 * * * \\
(0.0376)\end{array}$ & $\begin{array}{l}-0.0243 \\
(0.0941)\end{array}$ \\
\hline (log) Real State Income Per Capita ${ }_{i t}$ & & & $\begin{array}{c}-49.5418^{* * *} \\
(7.4705)\end{array}$ & $\begin{array}{c}-59.7220 * * \\
(29.5455)\end{array}$ \\
\hline (log) Real State Income Per Capita Squared ${ }_{i t}$ & & & $\begin{array}{c}2.5180 * * * \\
(0.3974)\end{array}$ & $\begin{array}{l}3.1724^{* *} \\
(1.4890)\end{array}$ \\
\hline Joint Hausman Test & \multicolumn{2}{|c|}{2.4559} & \multicolumn{2}{|c|}{3.9554} \\
\hline & \multicolumn{2}{|c|}{$[0.1171]$} & \multicolumn{2}{|c|}{$[0.2663]$} \\
\hline No. of states & \multicolumn{2}{|c|}{48} & \multicolumn{2}{|c|}{48} \\
\hline No. of observations & \multicolumn{2}{|c|}{2592} & \multicolumn{2}{|c|}{2592} \\
\hline
\end{tabular}

${ }^{\dagger}$ The dependent variable is income inequality indicator defined by the share of income held by the top 10 percent of the population (top10). The growth volatility is measured by the five-year moving average of the absolute values of the changes in the rate of growth (adg), as suggested by Pritchett (2000). The ARDL lag order is selected to be $(1, \cdot, 1)$ and all variables are mean-differenced to account for cross-state common factors. ***, **, and * indicates significant at 1-, 5-, and 10-percent levels, respectively. 
Table 3: Effects of Lagged Growth Volatility on Income Inequality

\begin{tabular}{l}
\hline \\
\cline { 2 - 4 } \\
\cline { 2 - 4 }
\end{tabular}


Table 4: Alternative Lag Orders

\begin{tabular}{|c|c|c|c|c|c|c|}
\hline & \multicolumn{2}{|c|}{ AIC } & \multicolumn{2}{|c|}{ SBC } & \multicolumn{2}{|c|}{ HQ } \\
\hline & PMG & MG & PMG & MG & PMG & MG \\
\hline \multicolumn{7}{|l|}{ Error Correction Coefficient } \\
\hline$\varphi$ & $\begin{array}{c}-0.3718^{* * *} \\
(0.0398)\end{array}$ & $\begin{array}{c}-0.5726 * * * \\
(0.0379)\end{array}$ & $\begin{array}{c}-0.4534 * * * \\
(0.0472)\end{array}$ & $\begin{array}{c}-0.5839 * * * \\
(0.0397)\end{array}$ & $\begin{array}{c}-0.3784^{* * *} \\
(0.0399)\end{array}$ & $\begin{array}{c}-0.5695^{* * *} \\
(0.0385)\end{array}$ \\
\hline \multicolumn{7}{|l|}{ Long-Run Coefficients } \\
\hline Growth Volatility ( adg $_{\mathrm{it}}$ ) & $\begin{array}{c}0.1517^{* * *} \\
(0.0355)\end{array}$ & $\begin{array}{l}-0.5136 \\
(0.6098)\end{array}$ & $\begin{array}{c}0.1324 * * * \\
(0.0326)\end{array}$ & $\begin{array}{l}-0.1863 \\
(0.2701)\end{array}$ & $\begin{array}{c}0.1581^{* * *} \\
(0.0349)\end{array}$ & $\begin{array}{l}-0.1972 \\
(0.2731)\end{array}$ \\
\hline (log) Real State Income Per Capita ${ }_{i t}$ & $\begin{array}{c}-38.6117^{* * * *} \\
(6.3668)\end{array}$ & $\begin{array}{c}-134.7767 * \\
(75.3230)\end{array}$ & $\begin{array}{c}-56.6932 * * * \\
(5.6639)\end{array}$ & $\begin{array}{c}-93.7080 * * \\
(39.8444)\end{array}$ & $\begin{array}{c}-39.5718^{* * *} \\
(6.2366)\end{array}$ & $\begin{array}{c}-99.8684 * * \\
(40.6484)\end{array}$ \\
\hline (log) Real State Income Per Capita Squared ${ }_{\text {it }}$ & $\begin{array}{c}2.0504 * * * \\
(0.3403)\end{array}$ & $\begin{array}{c}7.0225 * \\
(3.8759)\end{array}$ & $\begin{array}{c}2.9793^{* * *} \\
(0.3000)\end{array}$ & $\begin{array}{l}4.9747 * * \\
(2.0599)\end{array}$ & $\begin{array}{c}2.0891 * * * \\
(0.3325)\end{array}$ & $\begin{array}{l}5.2128 * * \\
(2.0932)\end{array}$ \\
\hline Joint Hausman Test & \multicolumn{2}{|c|}{1.8418} & \multicolumn{2}{|c|}{1.5760} & \multicolumn{2}{|c|}{2.3570} \\
\hline & \multicolumn{2}{|c|}{ [0.6059] } & \multicolumn{2}{|c|}{ [0.6648] } & \multicolumn{2}{|c|}{ [0.5017] } \\
\hline No. of states & \multicolumn{2}{|c|}{48} & \multicolumn{2}{|c|}{48} & \multicolumn{2}{|c|}{48} \\
\hline No. of observations & \multicolumn{2}{|c|}{2592} & \multicolumn{2}{|c|}{2592} & \multicolumn{2}{|c|}{2592} \\
\hline
\end{tabular}

† The dependent variable is income inequality indicator defined by the share of income held by the top 10 percent of the population (top10). The lagged growth volatility is measured by the five-year moving average of the absolute values of the changes in the rate of growth (adg) at $t-1$ period. The ARDL lag order is determined by the AIC, SBC and HQ criterion (up to three lags), respectively, and all variables are mean-differenced to account for cross-state common factors. ***, **, and * indicates significant at 1-, 5-, and 10-percent levels, respectively. 
Table 5: Alternative Controlling Variables

\begin{tabular}{|c|c|c|c|c|c|c|}
\hline \multirow[b]{3}{*}{ Error Correction Coefficient } & \multicolumn{2}{|c|}{$(1)$} & \multicolumn{2}{|c|}{$(2)$} & \multicolumn{2}{|c|}{ (3) } \\
\hline & PMG & MG & PMG & MG & PMG & MG \\
\hline & & & & & & \\
\hline$\varphi$ & $\begin{array}{c}-0.5230 * * * \\
(0.0510)\end{array}$ & $\begin{array}{c}-0.6824 * * * \\
(0.0411)\end{array}$ & $\begin{array}{c}-0.4850 * * * \\
(0.0496)\end{array}$ & $\begin{array}{c}-0.6223^{* * *} \\
(0.0405)\end{array}$ & $\begin{array}{c}-0.4718^{* * *} \\
(0.0497)\end{array}$ & $\begin{array}{c}-0.7170 * * * \\
(0.0440)\end{array}$ \\
\hline \multicolumn{7}{|l|}{ Long-Run Coefficients } \\
\hline Growth Volatility $\left(\operatorname{adg}_{\mathrm{it}}\right.$ ) & $\begin{array}{c}0.1136 * * * \\
(0.0267)\end{array}$ & $\begin{array}{c}0.3088 \\
(0.2513)\end{array}$ & $\begin{array}{c}0.1221^{* * *} \\
(0.0309)\end{array}$ & $\begin{array}{l}-0.1266 \\
(0.2415)\end{array}$ & $\begin{array}{c}0.1495^{* * * *} \\
(0.0310)\end{array}$ & $\begin{array}{c}0.1617 \\
(0.1160)\end{array}$ \\
\hline (log) Real State Income Per Capita ${ }_{\text {it }}$ & $\begin{array}{c}-53.4305^{* * *} \\
(5.9416)\end{array}$ & $\begin{array}{c}25.5869 \\
(112.9539)\end{array}$ & $\begin{array}{c}-54.5094 * * * \\
(5.5154)\end{array}$ & $\begin{array}{c}-106.2579 * * \\
(49.2144)\end{array}$ & $\begin{array}{c}-64.6271^{* * *} \\
(6.2099)\end{array}$ & $\begin{array}{l}-47.5308 \\
(34.7999)\end{array}$ \\
\hline (log) Real State Income Per Capita Squared ${ }_{i t}$ & $\begin{array}{c}2.8478 * * * \\
(0.3075)\end{array}$ & $\begin{array}{l}-1.0559 \\
(5.6484)\end{array}$ & $\begin{array}{c}2.8976^{* * * *} \\
(0.2929)\end{array}$ & $\begin{array}{l}5.5564 * * \\
(2.5057)\end{array}$ & $\begin{array}{c}3.4171^{* * *} \\
(0.3227)\end{array}$ & $\begin{array}{c}2.4635 \\
(1.7788)\end{array}$ \\
\hline (log) High School ${ }_{\text {it }}$ & $\begin{array}{c}-0.7795^{* *} \\
(0.3423)\end{array}$ & $\begin{array}{l}-11.4090 \\
(13.9084)\end{array}$ & & & $\begin{array}{l}-0.1462 \\
(0.3768)\end{array}$ & $\begin{array}{l}-6.1543 \\
(6.3400)\end{array}$ \\
\hline$(\log )$ College $_{i t}$ & & & $\begin{array}{c}-0.7748^{* * *} \\
(0.2994)\end{array}$ & $\begin{array}{c}1.7151 \\
(1.9110)\end{array}$ & $\begin{array}{c}-0.5856 * \\
(0.3069)\end{array}$ & $\begin{array}{c}4.8220 \\
(4.0887)\end{array}$ \\
\hline Joint Hausman Test & \multicolumn{2}{|c|}{1.2026} & \multicolumn{2}{|c|}{2.0076} & \multicolumn{2}{|c|}{ [0.4119] } \\
\hline No. of states & \multicolumn{2}{|c|}{48} & \multicolumn{2}{|c|}{48} & \multicolumn{2}{|c|}{48} \\
\hline No. of observations & \multicolumn{2}{|c|}{2592} & \multicolumn{2}{|c|}{2592} & \multicolumn{2}{|c|}{2592} \\
\hline
\end{tabular}


Table 6: Alternative Inequality Measures

\begin{tabular}{|c|c|c|c|c|c|}
\hline & \multicolumn{5}{|c|}{ PMG } \\
\hline & top1 & top9099 & gini & atkin05 & theil \\
\hline Error Correction Coefficient & & & & & \\
\hline$\varphi$ & $\begin{array}{c}-0.3206 * * * \\
(0.0243)\end{array}$ & $\begin{array}{c}-0.4579 * * * \\
{[0.0317]}\end{array}$ & $\begin{array}{c}-0.5431 * * * \\
(0.0496)\end{array}$ & $\begin{array}{c}-0.4388^{* * *} \\
{[0.0497]}\end{array}$ & $\begin{array}{c}-0.4976 * * * \\
(0.0489)\end{array}$ \\
\hline Long-Run Coefficients & & & & & \\
\hline Growth Volatility $\left(\right.$ adg $\left._{i t}\right)$ & $\begin{array}{c}0.0922 * * * \\
(0.0357)\end{array}$ & $\begin{array}{l}0.0805 * * \\
(0.0329)\end{array}$ & $\begin{array}{l}0.0975 * * \\
(0.0418)\end{array}$ & $\begin{array}{l}0.0741^{* *} \\
(0.0353)\end{array}$ & $\begin{array}{c}0.2702 * * * \\
(0.1006)\end{array}$ \\
\hline (log) Real State Income Per Capita ${ }_{i t}$ & $\begin{array}{l}-4.7177 \\
(7.4708)\end{array}$ & $\begin{array}{c}-60.4002 * * * \\
(5.3107)\end{array}$ & $\begin{array}{c}-36.6061 * * * \\
(7.4551)\end{array}$ & $\begin{array}{c}-76.3418^{* * *} \\
(6.9739)\end{array}$ & $\begin{array}{c}-218.4584 * * * \\
(17.7250)\end{array}$ \\
\hline$(\log )$ Real State Income Per Capita Squared ${ }_{i t}$ & $\begin{array}{r}0.2193 \\
(0.3938) \\
\end{array}$ & $\begin{array}{c}3.1591^{* * *} \\
(0.2774) \\
\end{array}$ & $\begin{array}{c}1.7176 * * * \\
(0.3997) \\
\end{array}$ & $\begin{array}{c}3.9663^{* * *} \\
(0.3613) \\
\end{array}$ & $\begin{array}{c}11.8990 * * * \\
(0.9341) \\
\end{array}$ \\
\hline Joint Hausman Test & $\begin{array}{c}3.9603 \\
{[0.2658]}\end{array}$ & $\begin{array}{c}1.5026 \\
{[0.6817]}\end{array}$ & $\begin{array}{c}3.9767 \\
{[0.2640]}\end{array}$ & $\begin{array}{c}4.4408 \\
{[0.2176]}\end{array}$ & $\begin{array}{c}4.1728 \\
{[0.2434]}\end{array}$ \\
\hline No. of states & 48 & 48 & 48 & 48 & 48 \\
\hline No. of observations & 2592 & 2592 & 2592 & 2592 & 2592 \\
\hline
\end{tabular}

${ }^{\dagger}$ The dependent variable is income inequality indicator defined, respectively, by (1) the income share of the top 1 percent (top1) population, (2) the income share of the top 90-99 percent (top9099) population, (3) Gini coefficient (gini), (4) the Atkinson index with inequality aversion parameter of 0.5 (atkin05), and (5) the Theil entropy index (theil). The growth volatility is measured by the five-year moving average of the absolute values of the changes in the rate of growth (adg), as suggested by Pritchett (2000). The lag orders are determined by the SBC criterion (up to three lags), and all variables are mean-differenced to account for cross-state common factors. ***, **, and* indicates significant at 1-, 5-, and 10-percent levels, respectively. 
Table 7: Alternative Volatility Measures

\begin{tabular}{|c|c|c|c|c|c|c|}
\hline & \multicolumn{6}{|c|}{ PMG } \\
\hline & $\mathrm{mg}_{\mathrm{it}}$ & $\operatorname{mdg}_{\mathrm{it}}$ & hg $_{\text {it }}$ & heg $_{\text {it }}$ & $\operatorname{hcg}_{\text {it }}$ & $\operatorname{adg}_{\text {it }}^{\text {ur }}$ \\
\hline $\begin{array}{l}\text { Error Correction Coefficient } \\
\varphi\end{array}$ & $\begin{array}{c}-0.4815^{* * *} \\
(0.0339)\end{array}$ & $\begin{array}{c}-0.3812^{* * *} \\
(0.0272)\end{array}$ & $\begin{array}{c}-0.3873^{* * *} \\
(0.0305)\end{array}$ & $\begin{array}{c}-0.3766 * * * \\
(0.0291)\end{array}$ & $\begin{array}{c}-0.3850 * * * \\
(0.0300)\end{array}$ & $\begin{array}{c}-0.5231^{* * *} \\
(0.0380)\end{array}$ \\
\hline Long-Run Coefficients & & & & & & \\
\hline Growth Volatility $\left(\mathrm{adg}_{\mathrm{it}}\right)$ & $\begin{array}{c}0.0929 * * * \\
(0.0250)\end{array}$ & $\begin{array}{c}0.0306 * \\
(0.0177)\end{array}$ & $\begin{array}{c}0.1810 * * * \\
(0.0395)\end{array}$ & $\begin{array}{c}0.1149 * * * \\
(0.0388)\end{array}$ & $\begin{array}{c}0.1947 * * * \\
(0.0446)\end{array}$ & $\begin{array}{l}0.2732 * * \\
(0.1391)\end{array}$ \\
\hline (log) Real State Income Per Capita ${ }_{\text {it }}$ & $\begin{array}{c}-44.4640 * * * \\
(6.0857)\end{array}$ & $\begin{array}{c}-78.4989 * * * \\
(7.6282)\end{array}$ & $\begin{array}{c}-35.9096 * * * \\
(6.5472)\end{array}$ & $\begin{array}{c}-33.2063^{* * *} \\
(6.5995)\end{array}$ & $\begin{array}{c}-27.5866 * * * \\
(6.5092)\end{array}$ & $\begin{array}{c}165.2329 \text { *** } \\
(45.8156)\end{array}$ \\
\hline (log) Real State Income Per Capita Squared $_{i t}$ & $\begin{array}{c}2.3408^{* * *} \\
(0.3209)\end{array}$ & $\begin{array}{c}4.1143^{* * *} \\
(0.4035)\end{array}$ & $\begin{array}{c}1.9074 * * * \\
(0.3527)\end{array}$ & $\begin{array}{c}1.7187^{* * *} \\
(0.3573)\end{array}$ & $\begin{array}{c}1.4451^{* * *} \\
(0.3515)\end{array}$ & $\begin{array}{c}-7.8527 * * * \\
(2.2656)\end{array}$ \\
\hline Joint Hausman Test & $\begin{array}{c}5.2125 \\
{[0.1569]}\end{array}$ & $\begin{array}{c}1.8838 \\
{[0.5969]}\end{array}$ & $\begin{array}{c}2.9406 \\
{[0.4009]}\end{array}$ & $\begin{array}{c}3.3883 \\
{[0.3355]}\end{array}$ & $\begin{array}{c}5.4581 \\
{[0.1412]}\end{array}$ & $\begin{array}{c}2.6024 \\
{[0.4571]}\end{array}$ \\
\hline No. of states & 48 & 48 & 48 & 48 & 48 & 48 \\
\hline No. of observations & 2592 & 2544 & 2766 & 2766 & 2766 & 1104 \\
\hline
\end{tabular}

${ }^{\dagger}$ The dependent variable is income inequality indicator defined by the share of income held by the top 10 percent of the population (top10). The growth volatility variable is defined, respectively, by (1) the five-year moving-sample standard deviations of the growth rates (mg), (2) the five-year moving standard deviation of the absolute values of the changes in the rate of growth (mdg), (3) the square root of fitted conditional variances from a GARCH model (hg), (4) the square root of fitted conditional variances from an exponential GARCH model (heg), (5) the square root of fitted conditional variances from a component GARCH model (hcg), and (6) the five-year moving average of the absolute values of the changes in the unemployment rate (adgur). The ARDL lag order is specified to be $(1,1,1)$ and all variables are mean-differenced account for cross-state common factors. ***, **, and * indicates significant at 1-, 5-, and 10-percent levels, respectively. 
Table 8: Alternative Time Period (1987-2004)

\begin{tabular}{|c|c|c|c|c|}
\hline \multirow[b]{3}{*}{ Error Correction Coefficient } & \multicolumn{2}{|l|}{$(1)$} & \multicolumn{2}{|l|}{$(2)$} \\
\hline & PMG & MG & PMG & MG \\
\hline & & & & \\
\hline$\varphi$ & $\begin{array}{c}-0.7103^{* * *} \\
(0.0347)\end{array}$ & $\begin{array}{c}-0.8194 * * * \\
(0.0414)\end{array}$ & $\begin{array}{c}-0.7879 * * * \\
(0.0479)\end{array}$ & $\begin{array}{c}-1.0519 * * * \\
(0.0410)\end{array}$ \\
\hline \multicolumn{5}{|l|}{ Long-Run Coefficients } \\
\hline Growth Volatility (adg ${ }_{\mathrm{it}}$ ) & $\begin{array}{c}0.2956 * * * \\
(0.0630)\end{array}$ & $\begin{array}{c}0.0980 \\
(0.2349)\end{array}$ & $\begin{array}{l}0.1528^{* *} \\
(0.0735)\end{array}$ & $\begin{array}{l}-0.1717 \\
(0.2090)\end{array}$ \\
\hline (log) Real State Income Per Capita ${ }_{i t}$ & & & $\begin{array}{c}-559.5093^{* * *} \\
(59.1257)\end{array}$ & $\begin{array}{l}-268.2375 \\
(334.7422)\end{array}$ \\
\hline (log) Real State Income Per Capita Squared ${ }_{i t}$ & & & $\begin{array}{c}27.6371^{* * *} \\
(2.8363)\end{array}$ & $\begin{array}{c}13.4938 \\
(16.3469)\end{array}$ \\
\hline \multirow[t]{2}{*}{ Joint Hausman Test } & \multicolumn{2}{|c|}{0.7625} & \multicolumn{2}{|c|}{3.6940} \\
\hline & \multicolumn{2}{|c|}{$[0.3825]$} & \multicolumn{2}{|c|}{$[0.2965]$} \\
\hline No. of states & \multicolumn{2}{|c|}{48} & \multicolumn{2}{|c|}{48} \\
\hline No. of observations & \multicolumn{2}{|c|}{816} & \multicolumn{2}{|c|}{816} \\
\hline
\end{tabular}

